\title{
AN IMPROVED STAINING PROTOCOL FOR THE ASSESSMENT OF ARBUSCULAR MYCORRHIZAL IN BRYOPHYTES
}

\author{
AGUSTINA C. COTTET ${ }^{1 *}$, JOSE M. SCERVINO ${ }^{1}$ y MARÍA I. MESSUTI
}

\begin{abstract}
Summary: The most accepted method for staining arbuscular mycorrhiza (AM) in vascular plants has been one proposed by Phillips \& Hayman in 1970. In particular, for the study of AM in bryophytes (s.I.) [Anthocerotophyta, Bryophyta (s.s.), Marchantiophyta] some authors have introduced modifications to this technique. Even though all these protocols stain AM, their main disadvantage is related to the result of material maceration (e.g. over-softening or completely destroying plant cells due to the high temperatures used, the high concentrations of reagents or the long-term exposure to aggressive chemicals). In order to optimise the results for the observation of AM in this group of plants, a modification is presented to the traditional staining technique. In the protocol here proposed, $70 \%$ ethanol is used as fixative and first clarifier, $1 \%$ potassium hydroxide $(\mathrm{KOH})\left(80{ }^{\circ} \mathrm{C}, 20 \mathrm{~min}\right)$ as a second clarifier; $1 \%$ hydrochloric acid $(\mathrm{HCl})\left(50{ }^{\circ} \mathrm{C}, 10 \mathrm{~min}\right)$ as an acidifier and $0.05 \%$ trypan blue $\left(60{ }^{\circ} \mathrm{C}, 20 \mathrm{~min}\right)$ for dyeing. This improved protocol is not destructive, it is fast to perform and it is of wide application since it allows staining the AM in bryophytes.
\end{abstract}

Key words: Anthocerotophyta, Bryophyta, Marchantiophyta, staining protocol.

Resumen: Un protocolo de tinción mejorado para la visualización de micorrizas arbusculares en briofitas. El método tradicional más aceptado para la tinción de micorrizas arbusculares (MA) en plantas vasculares es el propuesto por Phillips \& Hayman en 1970. En particular, para el estudio de las MA en briofitas (s.l.) [Anthocerotophyta, Bryophyta (s.s.), Marchantiophyta] algunos autores introdujeron modificaciones a esta técnica. Aunque todos estos protocolos tiñen las MA, su principal desventaja está relacionada con el resultado de la maceración del material (e.g. reblandecimiento excesivo o destrucción de las células vegetales por altas temperaturas utilizadas, altas concentraciones de reactivos o exposición prolongada a sustancias químicas agresivas). Para optimizar la observación de las MA en briofitas (s.l.), se desarrolló una adaptación a la técnica de tinción tradicional y sus modificaciones. En el protocolo aquí propuesto, se usa etanol $70 \%$ para fijar y como primer clarificador, hidróxido de potasio $(\mathrm{KOH}) 1 \%\left(80{ }^{\circ} \mathrm{C}, 20 \mathrm{~min}\right)$ como segundo clarificador; ácido clorhídrico $(\mathrm{HCl}) 1 \%\left(50^{\circ} \mathrm{C}, 10 \mathrm{~min}\right)$ como acidificante y azul de tripán $0,05 \%\left(60{ }^{\circ} \mathrm{C}, 20 \mathrm{~min}\right)$ para teñir. Este protocolo mejorado no es destructivo, es rápido de realizar y es de amplia aplicación ya que permite teñir las MA en briófitas (s.l.).

Palabras clave: Anthocerotophyta, Bryophyta, Marchantiophyta, protocolo de tinción.

\section{INTRODUCTION}

The most accepted method for staining arbuscular mycorrhiza (AM) in vascular plants is one proposed by Phillips \& Hayman (1970).

1 Instituto de Investigaciones en Biodiversidad y Medioambiente, Consejo Nacional de Investigaciones Científicas y Técnicas-Universidad Nacional del Comahue, Quintral 1250, 8400 San Carlos de Bariloche, Argentina.

*Author for correspondence: agustina.c.cottet@gmail.com
These authors, proposed fixation of root samples in formaldehyde-acetic acid-ethanol (FAA), then, clarify with $10 \%$ potassium hydroxide $(\mathrm{KOH})$ $\left(90{ }^{\circ} \mathrm{C}, 1 \mathrm{~h}\right)$; acidify with dilute hydrochloric acid $(\mathrm{HCl})$; and stained with $0.05 \%$ trypan blue in lactophenol (room temperature, $5 \mathrm{~min}$ ). Later, for the study of AM in plants included in bryophytes (s.l.), Anthocerotophyta, Bryophyta (s.s.) and Marchantiophyta, some authors have introduced modifications to the traditional protocol, such as temperature, time exposure, reagents concentration and type of dyes. For example, those proposed for Anthocerotophyta by Schüßler (2000), for 
Bryophyta (s.s.) by Zhang \& Guo (2007), and for Marchantiophyta by Silvani et al. (2012).

Even though all these protocols stain AM hyphae, their main disadvantage is related to the result of material maceration (e.g. over-softening or plant cell destruction due to the high temperatures used, the reagents high concentrations or the longtime exposure to aggressive chemicals).

The objective of this work was to adapt the traditional technique of Phillips \& Hayman (1970), and the subsequent modifications that were used in the study of AM of bryophytes (s.l.), allowing nondestructive staining of AM in representatives of this group of plants.

\section{Material and Methods}

\section{Collection of materials}

The specimens were collected by the random walk method. They were separated from the substrate by the aid of a knife and placed in properly labelled paper bags, and then taken to the laboratory for processing (Frahm, 2003).

\section{Material conditioning}

The collected specimens were conditioned with clamps and needles to extract the maximum possible substrate. In order to preserve them, from decomposing agents such as insects, they were placed for 7 days in a freezer at $-18{ }^{\circ} \mathrm{C}$ (Ardiles Huerta et al., 2008). The voucher specimens were deposited in BCRU herbarium.

\section{Testing of different staining methods}

Different proposed dyeing techniques were tested for mycorrhiza staining:

Phillips \& Hayman (1970). The fresh roots were rinsed with water and fixed in FAA; later, clarified with $10 \% \mathrm{KOH}\left(90^{\circ} \mathrm{C}, 60 \mathrm{~min}\right)$; bleached (for pigmented material) with hydrogen peroxide $\left(\mathrm{H}_{2} \mathrm{O}_{2}\right) 10$ vol $\left(20^{\circ} \mathrm{C}, 10-60 \mathrm{~min}\right)$; acidified with dilute $\mathrm{HCl}$; and stained with $0.05 \%$ trypan blue in lactophenol (at room temperature, $5 \mathrm{~min}$ ) (Fig. 1 A).

Koske \& Gemma (1989). The fresh roots were rinsed with water and fixed in $50 \%$ ethanol or isopropyl alcohol; later clarified with $2.5 \%$ $\mathrm{KOH}\left(121^{\circ} \mathrm{C}, 3 \mathrm{~min}\right.$ or $\left.90^{\circ} \mathrm{C}, 10-30 \mathrm{~min}\right)$; and, rinsed with water. If the roots have pigments they are bleached in $\mathrm{H}_{2} \mathrm{O}_{2}$ for 10-30 min; rinsed with water; acidified with $1 \% \mathrm{HCl}$ for (room temperature, 1-24 h); stained with trypan blue in acidic glycerol $\left(121^{\circ} \mathrm{C}, 3 \mathrm{~min}\right.$ or $90^{\circ} \mathrm{C}, 10-30$ min) (Fig. 1 B).

Ligrone \& Lopes (1989). Portions of the gametophytes were clarified with $10 \% \mathrm{KOH}$ $\left(90{ }^{\circ} \mathrm{C}, 1 \mathrm{~h}\right)$; stained with $0.05 \%$ trypan blue in lactophenol. Rhizoids are not clarified (Fig. 1 C).

Williams et al. (1994). The gametophytes were preserved in $70 \%$ ethanol and later fixed in acetic acid/ethanol (1:3 V/V) (Bryophyta) or frozen at $-20{ }^{\circ} \mathrm{C}$ (Marchantiophyta); cleaned and subsequently stained with the protocol proposed by Koske \& Gemma (1989).

Schüßler (2000). Portions of the gametophytes were extruded in agar/water culture; clarified with $10 \% \mathrm{KOH}\left(121{ }^{\circ} \mathrm{C}, 10 \mathrm{~min}\right)$; rinsed three times in water; acidified with $3.7 \% \mathrm{HCl}$ (at room temperature, $3 \mathrm{~min}$ ); stained with $0.05 \%$ trypan blue in lactophenol (Fig. 1 D).

Zhang \& Guo (2007). Whole gametophytes were rinsed and preserved in 50\% ethanol; clarified with $10 \% \mathrm{KOH}\left(92{ }^{\circ} \mathrm{C}, 20 \mathrm{~min}\right)$; acidified with lactic acid (at room temperature, $3 \mathrm{~min}$ ); stained with $0.5 \%$ acid fuchsin $\left(92^{\circ} \mathrm{C}, 20 \mathrm{~min}\right)$ (Fig. $1 \mathrm{E}$ ).

Fonseca et al. (2009). Segments of culture gametophytes were fixed in the Bouin's fluid; clarified with $10 \% \mathrm{KOH}\left(80^{\circ} \mathrm{C}, 20 \mathrm{~min}\right)$; rinsed with distilled water; acidified with $37 \% \mathrm{HCl}$; stained with $0.05 \%$ trypan blue in aqueous solution (Fig. $1 \mathrm{~F}$ ).

Hanke \& Rensing (2010). Portions of gametophyte's stems were taken from the culture; clarified with $10 \% \mathrm{KOH}\left(95{ }^{\circ} \mathrm{C}\right.$, several min); rinsed with water; acidified with $5 \% \mathrm{HCl}$ (at room temperature, $3 \mathrm{~min}$ ); stained with $1 \%$ trypan blue in aqueous solution (at room temperature, 10 min) (Fig. $1 \mathrm{G}$ ).

Newsham (2011). The gametophytes were rinsed with water; clarified with $10 \% \mathrm{KOH}$ (at room temperature, $72 \mathrm{~h}$ ); rinsed five times in water; acidified with 5\% lactic acid (at room temperature, $1 \mathrm{~h}$ ); stained with $0.01 \%$ aniline blue in lactic acid (at room temperature, $24 \mathrm{~h}$ ) (Fig. $1 \mathrm{H}$ ).

Liepina (2012). Whole gametophytes were clarified with $10 \% \mathrm{KOH}\left(90^{\circ} \mathrm{C}, 20 \mathrm{~min}\right)$; acidified with lactic acid and stained with $0.5 \%$ cotton blue in aqueous solution (at room temperature, $20 \mathrm{~min}$ ). 


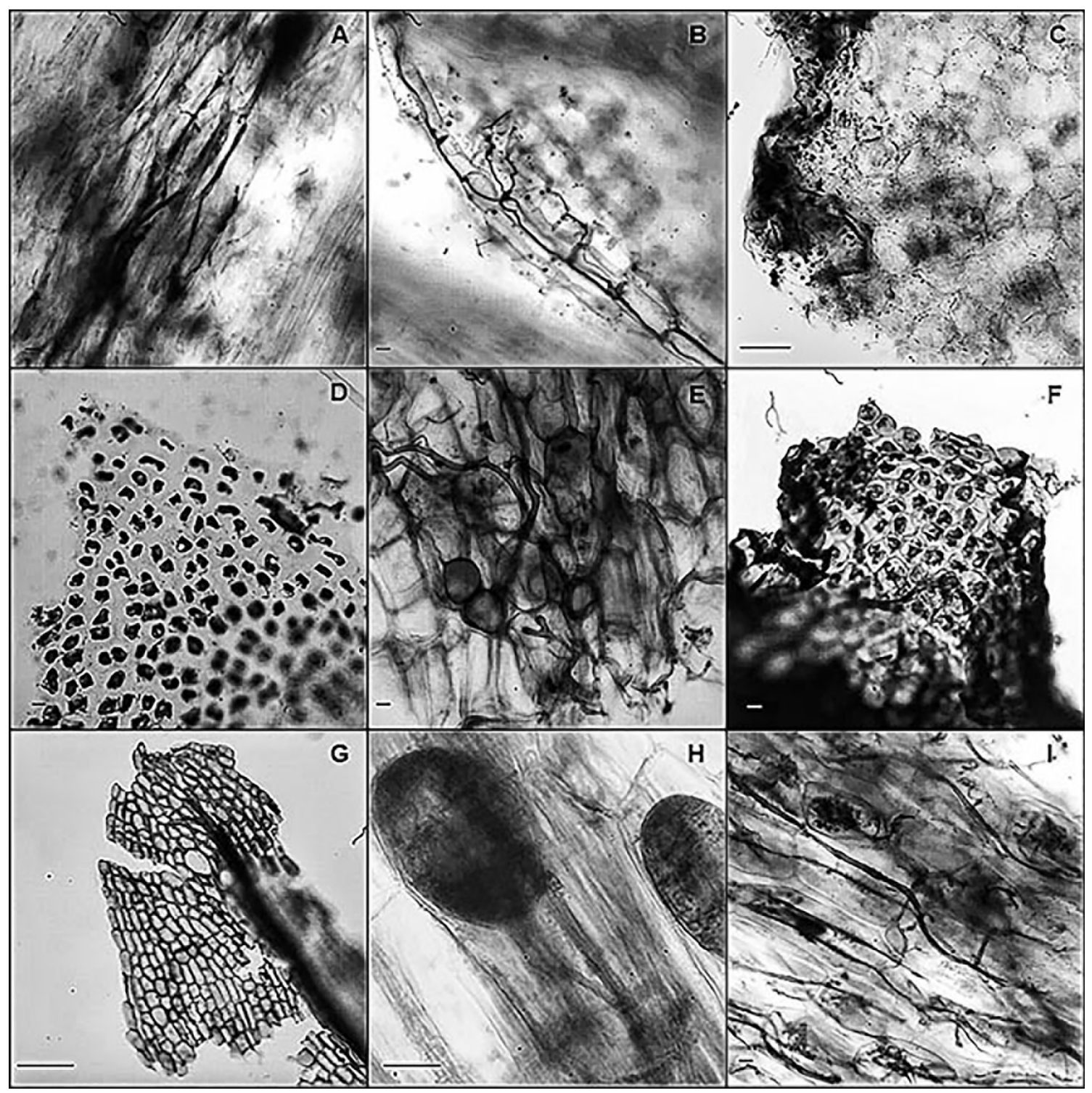

Fig. 1. Examples of testing of different staining methods for arbuscular mycorrhizal in bryophytes (s.I.). A: According to the protocol Phillips \& Hayman (1970), Marchantiophyta. B: According to the protocol Koske \& Gemma (1989), Bryophyta (s.s.). C: According to the protocol Ligrone \& Lopes (1989), Anthocerotophyta. D: According to the protocol Schüßler (2000), Marchantiophyta. E: According to the protocol Zhang \& Guo (2007), Anthocerotophyta. F: According to the protocol Fonseca et al. (2009), Marchantiophyta. G: According to the protocol Hanke \& Rensing (2010), Bryophyta (s.s.). H: According to the protocol Newsham (2011), Anthocerotophyta. I: According to the protocol Fonseca et al. (2014), Marchantiophyta. Scale bars $=10 \mu \mathrm{m}$ (Figs A-G, I); $100 \mu \mathrm{m}$ (Fig H).

Silvani et al. (2012). Portions of culture gametophytes were clarified with $15 \% \mathrm{KOH}(25$ ${ }^{\circ} \mathrm{C}, 48 \mathrm{~h}$ ); acidified with $4 \% \mathrm{HCl}$ and stained with $0.1 \%$ trypan blue in lactic acid.
Fonseca et al. (2014). The gametophytes were fixed in $70 \%$ ethanol; clarified with $10 \% \mathrm{KOH}$ $\left(80{ }^{\circ} \mathrm{C}, 20 \mathrm{~min}\right)$; rinsed with distilled water; acidified with $37 \% \mathrm{HCl}$ and stained with 
$0.05 \%$ trypan blue in aqueous solution $\left(60{ }^{\circ} \mathrm{C}\right.$, 20 min) (Fig. 1 I).

Newsham et al. (2014). The gametophytes were clarified with $10 \% \mathrm{KOH}$ (at room temperature, $24 \mathrm{~h}$ ); rinsed three times in water; bleached with solution of $7.5 \% \quad \mathrm{H}_{2} \mathrm{O}_{2}$ and $0.7 \%$ ammonium hydroxide (at room temperature, 3 min); acidified with 5\% lactic acid (at room temperature, $1 \mathrm{~h}$ ) and stained with $0.01 \%$ aniline blue in lactic acid (at room temperature, $24 \mathrm{~h})$.

Verma \& Langer (2014). The gametophytes were clarified with $0.01 \% \mathrm{KOH}\left(100{ }^{\circ} \mathrm{C}, 2-3 \mathrm{~h}\right.$, and later kept at room temperature, $1 \mathrm{~h}$ ); rinsed three or four times in water and stained with trypan blue in lactophenol.

Observation of stained gametophytes with the tested protocols

To observe the result obtained after the application of each protocol tested, the gametophytes were cut in sagittal sections with a razor blade, and examined under an optical microscope. All photographs for Figs. 1 and 2 were taken using a compound microscope Olympus BX50, connected to a Lumenera Infinity 1 digital camera.

\section{Results}

For the visualization of AM in gametophytes, all the techniques tested in this work showed significant softening of the material and morphological and anatomical modifications of the tissues. Hence, we present a modification to the different techniques used for staining of AM, which allows the visualization of AM in the bryophytes (s.l.) (Fig. 2).

The proposed protocol consists of cleaning the gametophytes with water and fixing them in $70 \%$ ethanol. Subsequently, clarify them in two steps: first, using the fixing agent at $50{ }^{\circ} \mathrm{C}$ until the total evaporation of the liquid, and rinsing the gametophytes once in water; and second, using $1 \% \mathrm{KOH}\left(80{ }^{\circ} \mathrm{C}, 20 \mathrm{~min}\right)$; rinse the gametophytes one time in water. Then acidify with $1 \% \mathrm{HCl}(50$ ${ }^{\circ} \mathrm{C}, 10 \mathrm{~min}$ ); rinse the gametophytes once in water. Finally stain with $0.05 \%$ trypan blue in aqueous solution $\left(60{ }^{\circ} \mathrm{C}, 20 \mathrm{~min}\right)$; rinse the gametophytes twice in water.

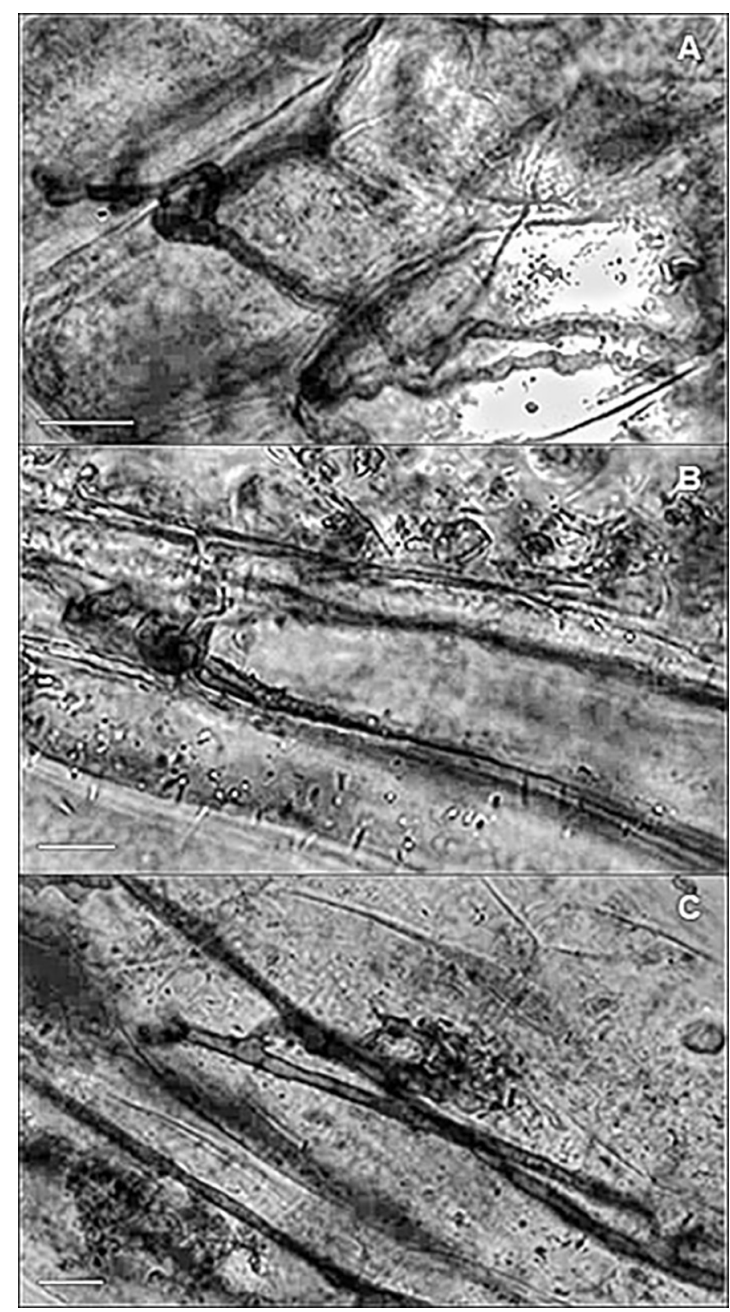

Fig. 2. Examples of gametophytes staining with the new improved protocol for the observation of arbuscular mycorrhizal. A: Anthocerotophyta. B: Bryophyta (s.s.). C: Marchantiophyta. Scale bars = $10 \mu \mathrm{m}$.

\section{Discussion}

While in the past vascular plants roots were fixed in FAA, the gametophytes of bryophytes were fixed with $50 \%$ ethanol or $70 \%$ ethanol or acetic acid/ethanol $(1: 3 \mathrm{~V} / \mathrm{V})$ or preserved in freezer at $-20{ }^{\circ} \mathrm{C}$ without fixer. The advantages of working with $70 \%$ ethanol are that it preserves the material under optimum conditions, both its morphology and anatomy, and that when it is fixed the process of clarification begins, which is the first step of the staining protocol. 
In all tested protocols in this work (see above) the clarification of the material is done with $\mathrm{KOH}$, however there is no regularity regarding the concentration, temperature and time of exposure between them. The concentration ranges from $0.01 \%$ to $15 \%$, the temperature from $25{ }^{\circ} \mathrm{C}$ (at room temperature) to $121^{\circ} \mathrm{C}$ and the exposure time from $3 \mathrm{~min}$ to $72 \mathrm{~h}$. Generally speaking, when the concentration $(10 \%)$ and the temperature $\left(121{ }^{\circ} \mathrm{C}\right)$ increase, the time is reduced ( 3 to $10 \mathrm{~min}$ ); this is very harmful for the plant cells, which are partially or totally destroyed, and subsequent visualization of AM cannot be realised. On the other hand, if the concentration (15\%) is increased and the temperature is reduced, the exposure time is prolonged (24-72 h); although in this case the cells are not destroyed, this method requires a long-time to be finished. In the method here presented, a first clarification is proposed with $70 \%$ ethanol $\left(50{ }^{\circ} \mathrm{C}\right.$, until total liquid evaporation) and a second clarification with $1 \%$ $\mathrm{KOH}\left(80^{\circ} \mathrm{C}, 20 \mathrm{~min}\right)$. The first clarification causes a partial decolourization that dehydrates the cells allowing a greater penetration of the $\mathrm{KOH}$ in the second clarification; this method is quick to perform and does not destroy the gametophytes.

In order to bleach pigmented plants, some methods propose using $\mathrm{H}_{2} \mathrm{O}_{2}$ to depigment roots and gametophytes cells. Instead, this new protocol presents two stages of clarification, where this last bleaching step is not necessary, as the cells are sufficiently clarified for the correct visualization of AM.

The acidification process, in the past, employed mainly two acids, $\mathrm{HCl}$ and lactic acid, the concentrations of which varied from $1 \%$ to $5 \%$ and $5 \%$ to $85 \%$ respectively. Both methods of acidification were performed at room temperature and the exposure time ranged from $3 \mathrm{~min}$ to $24 \mathrm{~h}$ for $\mathrm{HCl}$ and from $3 \mathrm{~min}$ to $1 \mathrm{~h}$ for lactic acid. The use of $\mathrm{HCl}$ presents advantages in that it does not destroy the material, which maintains its original texture, whereas the use of lactic acid converts the material to a "gummy" texture that does not allow precision in the sagittal cutting of the gametophytes. In the past, as for the wide ranges for $\mathrm{HCl}$ concentrations, namely $1 \%$ to $37 \%$, none of the tested methods deteriorated the material. In this modified staining technique, there is applied only a low concentration of $\mathrm{HCl}(1 \%)$, and the temperature is increased to reduce the exposure time $\left(50^{\circ} \mathrm{C}, 10 \mathrm{~min}\right)$.
Finally, with regard to the staining stage, the dye commonly used is trypan blue, although others, such as acid fuchsin, aniline blue and cotton blue, are also used less frequently. The main variations regarding the use of trypan blue consist in the compounds in which the solution is made (lactophenol, lactic acid, water and acidic glycerol). For the study of AM in bryophytes it is here proposed to use trypan blue in aqueous solution $(0.05 \%)$, since the material retains the original texture and the sagittal cuts of the gametophyte can be made for ease of observation of AM.

Although the tested methods have been used previously with some favourable results for the study of bryophytes, they can be destructive or impractical. From our observations, we can say that the protocol here presented is not destructive, it is fast to perform, and it is of wide application since it may be used to stain AM in representatives of the three phyla of bryophytes.

\section{ACKNOWLEDgements}

This work was funded by Consejo Nacional de Investigaciones Científicas y Técnicas (CONICET) and Universidad Nacional del Comahue (UNComahue).

\section{BibliogRAPHY}

ARDILES HUERTA, V., J. CUVERTINO \& F. OSORIO. 2008. Guía de campo briofitas de los bosques templados australes de Chile. Una introducción al mundo de los musgos, hepáticas y antocerotes que habitan los bosques de Chile. Concepción: Corporación Chilena de la Madera.

FONSECA, H. M. A. C., R. L. BERBERA \& M. L. PEREIRA. 2014. Monoxenic cultures of light sensitive arbuscular mycorrhizal fungi with Lunularia cruciata (Marchantiopsida). Nova Hedwigia 98: 79-87.

FONSECA, H. M. A. C., J. I. L. FERREIRA, R. L. L. BERBARA \& N. P. ZATORRE. 2009. Dominance of Paris-type morphology on mycothallus of Lunularia cruciata colonised by Glomus proliferum. Braz. J. Microbiol. 40: 96-101.

FRAHM, J. P. 2003. Manual of tropical bryology. Trop. Bryol. 23: 1-200.

HANKE, S. T. \& S. A. RENSING. 2010. In vitro association of non-seed plant gametophytes with arbuscular mycorrhiza fungi. Endocytobiosis Cell. Res. 20: 95-101. 
KOSKE, R. E. \& J. N. GEMMA. 1989. A modified procedure for staining roots to detect VA mycorrhizas. Mycol. Res. 92: 486-505.

LIEPINA, L. 2012. Occurrence of fungal structures in bryophytes of the boreo-nemoral zone. Environ. Exp. Bot. 10: 35-40.

LIGRONE, R. \& C. LOPES. 1989. Cytology and development of a mycorrhiza-like infection in the gametophyte of Conocephalum conicum (L.) Dum. (Marchantiales, Hepatophyta). New Phytol. 111: 423-433.

NEWSHAM, K. K., M. P. GOODALL-COPESTAKE, R. OCHYRA \& J. VÁŇA. 2014. Mycothalli of the hepatic Barbilophozia hatcheri in Antarctica: distribution and identities of mycobionts. Fungal Ecol. 11: 91-99.

NEWSHAM, K. K. 2011. Structural changes to a mycothallus along a latitudinal transect through the maritime and sub-Antarctic. Mycorrhiza 21: 231236.

PHILLIPS, J. M. \& D. S. HAYMAN. 1970. Improved procedures for clearing roots and staining parasitic and vesicular-arbuscular mycorrhizal fungi for rapid assessment of infection. Trans. Br. Mycol. Soc. 55: 158-161.
SCHÜ $\beta$ LER, A. 2000. Glomus claroideum forms an arbuscular mycorrhiza-like symbiosis with the hornwort Anthoceros punctatus. Mycorrhiza 10: 15-21.

SILVANI, V. A., C. P. ROTHEN, M. A. RODRÍGUEZ, A. GODEAS \& S. FRACCHIA. 2012. The thalloid liverwort Plagiochasma rupestre supports arbuscular mycorrhiza-like symbiosis in vitro. World J. Microbiol. Biotechnol. 28: 3393-3397.

VERMA, M. \& A. LANGER. 2014. Studies on AM associations in Marchantia nepalensis L. et L. J. Pharm. Biol. Sci. 9: 26-29.

WILLIAMS, P. G., D. J. ROSER \& R. D. SEPPELT. 1994. Mycorrhizas of hepatics in continental Antarctica. Mycol. Res. 98: 34-36.

ZANG, Y. \& L. D. GUO. 2007. Arbuscular mycorrhizal structure and fungi associated with mosses. Mycorrhiza 17: 319-325.

Recibido el 28 de noviembre de 2017, aceptado el 18 de abril de 2018. Editor: Guillermo Suárez. 